\author{
Magdalena Lachman \\ Uniwersytet Łódzki \\ magdam@uni.lodz.pl
}

\title{
(Para)literacki wymiar reklamy
}

\section{(Para)literary dimension of advertising}

Summary: The impulse to write this article came with the recognition that among the various ways to define and characterize advertising the ones which emphasize - either intentionally or unintentionally - the variously understood (para)literary nature of the phenomenon occupy a prominent position. The belief that advertising can be regarded as a variety or specific manifestations of literature reveals itself on various occasions and in a wide variety of sources (not necessarily oriented towards literary studies): in academic research, literary criticism, essay and column writing, journalism and popular publications. The author does not seek to determine whether and under what conditions advertising complies with the requirements of a literary work, but rather adopts a reconstructive attitude and looks for an answer to the question, due to what properties and factors advertising is sometimes viewed in literary (or, more broadly, artistic) terms, and what arguments are used in support of this thesis, as well as what results from this type of beliefs for literary art itself, its condition, cultural rank and status quo.

Keywords: advertising, literature, literary, aesthetic, work of art, communication

Streszczenie: Impulsem do napisania artykułu było rozpoznanie, że wśród różnych sposobów definiowania i dookreślania reklamy eksponowaną pozycję zajmują ujęcia świadomie lub mimowolnie akcentujące rozmaicie pojmowaną (para)literackość zjawiska. Przekonanie, że reklama może stanowić odmianę czy specyficzny przejaw literatury, daje o sobie znać przy bardzo różnych okazjach i w różnorodnych źródłach (niekoniecznie tylko zorientowanych literaturoznawczo): w pracach naukowych, w krytyce, eseistyce, felietonistyce, publicystyce i w publikacjach popularyzatorskich. Autorka nie dąży do rozstrzygnięcia, czy i pod jakimi warunkami reklama spełnia wymogi dzieła literackiego, ale przyjmuje postawę rekonstrukcyjną i szuka odpowiedzi na pytanie, za sprawą jakich właściwości i czynników reklama bywa rozpatrywana w kategoriach literackich (czy szerzej: artystycznych) i jakich argumentów używa się na poparcie tej tezy, a także co z tego typu przeświadczeń w konsekwencji wynika dla samej sztuki słowa, jej kondycji, kulturowej rangi i status quo.

Słowa kluczowe: reklama, literatura, literackość, estetyka, dzieło sztuki, komunikacja 
Choć reklama jest zjawiskiem od dawna poddawanym rozmaitym diagnozom, ciągle trudno mówić o istnieniu wyspecjalizowanej i autonomicznej dziedziny, która respektowałaby specyfikę swojego przedmiotu zainteresowań i dostosowywała do niego swoiste tylko dlań narzędzia analityczne. Reklamoznawstwo $^{1}$ jawi się bardziej jako zespół zawodowych umiejętności niż precyzyjna teoria zjawiska. Jakkolwiek nie przestaje być artykułowana potrzeba różnorakiego, w tym także teoretycznego namysłu nad tym kulturowym fenomenem, przy rozpatrywaniu reklamy ścierają się i nakładają na siebie ciągle różne stanowiska badawcze (co być może warto uznać w ogóle za jej istotny rys). Bywa ona analizowana z perspektywy ekonomicznej, prawnej, antropologicznej, filozoficznej, historycznej, lingwistycznej, retorycznej, kulturoznawczej, medioznawczej, estetycznej... Dość eksponowaną pozycję zajmują w tym konglomeracie ujęcia akcentujące - z pełną samoświadomością lub w sposób mimowolny - (para)literackość zjawiska.

Przekonanie, że reklama może stanowić pełnoprawną odmianę literatury czy - w mniej radykalnej wersji - specyficzny jej przejaw ${ }^{2}$, daje o sobie znać przy bardzo różnych okazjach nie tylko w kręgach akademickich i w tekstach naukowych, formułują je również krytycy, eseiści i felietoniści, autorzy prac publicystycznych i popularyzatorskich. Robią to zresztą niekoniecznie w tekstach docelowo dotyczących reklamy, co tym bardziej wymowne, pokazuje bowiem namacalnie, jakimi wyobrażeniami na temat zjawisk kultury dysponują jej diagności i uczestnicy. W sposób dobitny wyraz takiemu stanowisku daje na przykład Daniel J. Boorstin:

Reklama - ta wszechobecna, charakterystyczna dla Ameryki odmiana literatury ujawniła swoją potęgę dopiero w drugiej połowie XIX wieku. Pod względem popularności ten nowy gatunek literacki nie miał sobie równych w historii światowego piśmiennictwa. W połowie XX wieku wszystkie inne gatunki literackie w Ameryce znalazły się w cieniu reklamy słownoobrazowej, jeśli idzie o siłę oddziaływania na

${ }^{1} \mathrm{Na}$ polskim gruncie to pojęcie funkcjonuje przede wszystkim w praktyce edukacyjnej na określenie kierunków kształcenia policealnego i akademickiego, których absolwenci są przygotowywani do pracy w agencjach reklamowych, domach mediowych, spółkach medialnych, działach promocji firm itp.

2 Aczkolwiek daleko do osiągnięcia pod tym względem konsensusu, o czym świadczy chociażby głos Anny Łebkowskiej: „pojęcie literatury ulega rozszerzeniu, poprzez próby rozszczelnienia kanonu, próby wprowadzenia w jego obręb nowych form; na przykład gatunkowych, czy innych - niż dotychczas - obiegów itd. (...). Nie dziwi też kariera literatury etnograficznej, podróżniczej czy różnych odmian autobiografizmu, biografistyki, form epistolarnych. O tym już dobrze wiemy i z grubsza tę sytuację aprobujemy. Jednakże propozycje idą znacznie dalej: na przykład niekiedy pojawiają się pomysły, by wcielić w obręb literatury nie tylko dzieła historyków i filozofów (w tym nie byłoby jeszcze nic dziwnego), ale także na przykład teksty reklam. Tak daleko posunięte rozszerzenie odległe jest nie tylko od przywołanych przed chwilą opcji, dalekie jest nawet od perspektywy pragmatystycznej” (A. Łebkowska, Między antropologia literatury i antropologia literacka, ,"Teksty Drugie” 2007, nr 6, s. 19). 
odbiorcę. (...) Reklama, wyzwolona z typograficznych okowów, ewoluowała powoli w niezależny genre literacki. Przez całe nadchodzące stulecie reklama miała kształtować amerykański język, stawiać nieznane dotąd wymagania pisarzom i faszerować publiczność słuchającą i czytającą mnogością łatwo wpadających w ucho, trywialnych zbitek słownych ${ }^{3}$.

O literackim nacechowaniu reklamy jest mowa w rozpoznaniach biorących pod uwagę nie tylko potencjalne uwarunkowania i powinowactwa zjawiska (na przykład według Barbary Stern „reklama różni się od komunikacji nieformalnej, gdyż w przeciwieństwie do niej jest komunikatem wysoce ustrukturyzowanym, zupełnie jak dzieło literackie” ${ }^{4}$ ), ale także jego pożądany kierunek rozwoju:

W naszych, pośpiesznych czasach chodzi właśnie o informację krótką, treściwą, zwięzłą i ciekawą. I to jest chyba przyszłość nowych przekaźników reklamowych, które w sposób literacki podadzą wszelkie istotne zalety i korzyści, jakie potencjalny klient może uzyskać, kupując ten a nie inny produkt. (...) chcę zasugerować, iżby wszelkie reklamowanie nowych potrzeb, nowych produktów, wychodzenie na rynek konsumenta itp. procesy były prowadzone z kulturą literacką. Żeby owa „sałata” stała się strawniejsza, wyrabiała wyobraźnię, a nawet była swoistym przekazem literackim5.

Asumpt do aprobowania (para)literackiego charakteru reklamy dają poniekąd pomysły, by placówki zajmujące się jej badaniem sytuować w obrębie wydziałów filologicznych, w tym również instytutów, katedr czy zakładów o profilu literaturoznawczym, na przykład Georges Elgozy (co znamienne: ekonomista i socjolog) już pod koniec lat sześćdziesiątych XX wieku wysuwał projekt powołania we Francji Centrum Twórczości Reklamowej i za najbardziej właściwe jego ulokowanie uznawał Ośrodek Stosowanych Studiów Literackich na Sorbonie ${ }^{6}$. Podobny wymiar sankcjonujący mają osobne hasła po-

3 D.J. Boorstin, Amerykanie. Fenomen demokracji, tłum. J. Kozak, Warszawa 1995, s. 141, 148. W tym i następnych cytatach, o ile nie zaznaczono inaczej, wszystkie wyróżnienia są moje - M.L.

${ }^{4}$ Tę opinię przytacza J. Szymkowska-Bartyzel, „Nie mów, że chcesz go ztowić”, czyli reklama zakamuflowana [w:] Kultura popularna, red. W. Godzic, A. Fulińska, M. Filiciak, Kraków 2002, s. 196.

5 W. Šmid, Metamarketing, Kraków 2000, s. 107.

${ }^{6}$ G. Elgozy, Paradoksy reklamy. Perswazja legalna, tłum. K. Błoński, wstęp K.T. Toeplitz, Warszawa 1973, s. 133 (pierwodruk francuski: Les Paradoxes de la Publicité, Paris 1969). Nie jest łatwo rozstrzygnąć, czy włączanie refleksji nad reklamą do programów uniwersyteckich na wydziałach humanistycznych (zajęcia jej poświęcone coraz powszechniej odbywają się obecnie na kierunkach filologicznych czy historii sztuki) oraz powoływanie w ich ramach wyspecjalizowanych jednostek, zajmujących się jej badaniem, jest wynikiem przeobrażeń w obrębie dyscyplin pod wpływem wymogów cywilizacyjnych i jawi się jako odpowiedź na zapotrzebowanie 
święcane reklamie w sprofilowanych literaturoznawczo leksykonach, takich jak Stownik terminów literackich czy Stownik literatury popularnej ${ }^{7}$. Nawet jeśli te źródła nie wypowiadają się jednoznacznie w kwestii przynależności reklamy do obszaru anektowanego przez sztukę słowa, tworzą one podstawy do konkretnych rozstrzygnięć, na przykład Małgorzata Kita, idąc między innymi tropem dyrektyw zawartych w drugim z wymienionych kompendiów, bez wahania uznaje reklamę za gatunek literatury popularnej:

Wskażmy odmiany i gatunki literatury popularnej, przyciągające uwagę językoznawców. Są to więc: romans, melodramat, literatura „kobieca”, literatura science fiction, literatura erotyczna, komiks, powieść kryminalna (zwłaszcza „policyjna”), teksty literackie wtórne wobec scenariuszy filmowych, antologia, biografia i autobiografia, teksty kabaretowe, piosenka, reklama, poradniki etykiety. (...) Opracowania monograficzne z zakresu językoznawstwa w całości związane $\mathrm{z}$ literaturą popularną należą na razie do rzadkości. Wymienić tu można książki dotyczące np. tekstów kabaretowych (...) i reklamowych ${ }^{8}$.

Dostrzeganie w reklamie mniej lub bardziej silnego literackiego uwarunkowania poza wszystkim rodzi pytanie o szczegółowe usytuowanie zjawiska w obrębie zasobów sztuki słowa; wyłania także następującą wątpliwość: czy włączenie reklamy do form literackich wpisuje się w zastane podziały i klasyfikacje, czy też - wręcz przeciwnie - wymaga stworzenia nowych typologii i porządków genologicznych (a może też definicji literatury) odmiennych od dotychczasowych. W świetle pojawiających się kwalifikacji nie jest wcale łatwo rozstrzygnąć, jaką, choćby czysto potencjalnie, odmianę literatury (szczególnie jeśli pozostać przy jej tradycyjnym pojmowaniu) ma stanowić reklama, nawet jeśli komentatorzy zdają się konkretne ujęcia faworyzować. Warto co najwyżej odnotować, że wśród dokonywanych identyfikacji - również w publicystyce i ujęciach potocznych - często zrównuje się reklamę z liryką (jest to wymowne, nawet jeśli działa w tym wypadku metaforyczny wymiar uogólnienia i arbitralny tok skojarzeń z obiegowo rozumianą aurą poetyckości, która

między innymi rynku pracy, czy też stanowi jednak pośredni dowód na potrzebę rozpatrywania reklamy pod kątem estetycznych właściwości i w konfrontacji ze zjawiskami artystycznymi, dlatego że taki kontekst wydaje się dla niej bardzo albo najbardziej adekwatny.

7 M. Głowiński, Reklama [w:] Stownik terminów literackich, red. J. Sławiński, wyd. 3 poszerz. i popr., Wrocław 1998, s. 466; E. Mrowczyk, Reklama [w:] Stownik literatury popularnej, red. T. Żabski, Wrocław 1997, s. 354-357.

${ }^{8}$ M. Kita, Literatura popularna w perspektywie jezykoznawczej [w:] Polonistyka w przebudowie. Literaturoznawstwo - wiedza o jezzyku - wiedza o kulturze - edukacja. Zjazd Polonistów, Kraków, 22-25 września 2004, red. M. Czermińska i in., t. 2, Kraków 2005, s. 288. Paradoksalnie, na dowód swojej tezy badaczka przytacza w przypisie pracę J. Bralczyka, Język na sprzedaż, czyli o tym, jak jezzyk stuży reklamie i jak reklama używa języka, wyd. 2, Gdańsk 2004, której autor bynajmniej nie traktuje reklamy jako odmiany literackiej. 
roztaczać się ma nad różnymi przejawami ludzkiej aktywności). Na przykład Wiesław Godzic w felietonie prasowym, zafascynowany skalą i technikami oddziaływania reklamy (zwłaszcza telewizyjnej), podchodzi do niej jako do „dostępnej na skalę masową poezji” i stwierdza: „Trzeba śmiało powiedzieć, że copywriter to poeta samiutkiego końca XX wieku”'; z kolei Anna Nasiłowska uznaje, że „reklamy tworzą skomplikowany świat metafor, zwielokrotniających luster, które posługują się rzeczywistością jako poetyckim materiałem"10, niektóre zaś towarowe identyfikatory lub slogany aż się proszą o dokonywanie poetyckich parafraz:

Marki i nazwy produktów zostają też nasycone poetycką energią.

Położyłem serce lwa

na słonecznym promieniu

- tak mogłaby się zacząć opowieść o śniadaniu złożonym z sera „Coeur du lion” i margaryny „Rayon du soleil’, gdyby oczywiście wszystko przetłumaczyć i usunąć cudzysłowy ${ }^{11}$.

Tomasz Stępień natomiast dostrzega zmaterializowaną na billboardach „poezję ulicy” i poddaje ją analizie z perspektywy dwudziestowiecznych postulatów i dokonań literackich właściwych zwłaszcza formacjom awangardowym $^{12}$. Również dla Leo Spitzera, autora opublikowanej w 1949 roku klasycznej już pracy dotyczącej reklamowej specyfiki, pozostaje „niekwestionowany fakt odbioru standardowej poezji reklamy przez szeroką publicznośc”, jako że „Handel ucieka się do poezji, gdyż docenia jej magnetyczną siłę we współczes-

9 W. Godzic, Reklama, czyli poezja masowa, „Gazeta Telewizyjna”, dod. do „Gazety Wyborczej” 2000, nr 95, s. 9. Poezja stanowi również punkt odniesienia przy charakterystyce reklamy w wypowiedziach, których intencją jest przedstawić tę technikę komunikacyjną w niezbyt pochlebnym czy wręcz deprecjonującym świetle - por. na przykład ujęcie, które prezentuje polemicznie przywoływany przez L. Spitzera (Amerykańska reklama jako sztuka popularna, tłum. K. Biskupski [w:] Jezzyk i spoteczeństwo, red. M. Głowiński, Warszawa 1980, s. 363-364) S.I. Hayakawa (Poetry and Advertising, „ETC. A Review of General Semantics” 1946, t. 3, nr 2, s. 116-120), według którego reklama jako utylitarny gatunek wypowiedzi jest przykładem „poezji skorumpowanej", niewyrażającej uczuć i przesłań w sposób czysty i bezinteresowny. Zob. też G. Majkowska, Jezyk reklamy [w:] Polszczyzna ali Polacy u schytku XX wieku, red. K. Handke, H. Dalewska-Greń, Warszawa 1994, s. 322: „50 lat temu Hayakawa nadał reklamie miano poezji skorumpowanej, poezji komiwojażera".

${ }^{10}$ A. Nasiłowska, O cudownych skutkach herbatki z melisy, „Teksty Drugie” 1991, nr 5, s. 139.

11 Tamże, s. 142.

12 T. Stępień, Poezja ulicy [w:] Dwudziestowieczna ikonosfera $w$ literaturach europejskich. Wizualizacja $w$ literaturze, red. B. Tokarz, Katowice 2002, s. 105-122 (ten artykuł opublikowany został wcześniej w „Opcjach” 2001, nr 3-4, s. 76-81; później zaś wszedł w skład książki T. Stępnia, Zabawa - poetyka - polityka, Katowice 2002, s. 184-200). 
nym odartym z poezji świecie"13. Spitzer, widząc w reklamie odmianę sztuki stosowanej (badacz posługuje się niemieckim określeniem Gebrauchskunst), wybiera do jej analizy „filologiczną metodę explication de texte” i stwierdza:

Będę się starał analizować tę reklamę tak, jak poemat św. Jana od Krzyża albo list Woltera, to znaczy - w sposób nieuprzedzony. Wierzę bowiem, iż ten typ sztuki, choć jego ranga jest bez porównania niższa niż ranga tekstów zazwyczaj analizowanych przez badaczy, także tworzy „tekst”, w którego słowach, chwytach literackich i rozwiązaniach graficznych kryje się duch naszego czasu i narodu ${ }^{14}$.

Wprawdzie nie wszyscy interpretatorzy zjawiska zgadzają się na zrównywanie reklamy z formami artystycznymi ${ }^{15}$, akcentując przede wszystkim różnicę w jej funkcjonowaniu ${ }^{16}$, jednak i oni nie przeczą możliwość aplikacji do

${ }^{13}$ L. Spitzer, dz. cyt., s. 365, 341. Jednocześnie badacz przyznaje, że „»Poezja reklamy« nie może, oczywiście, być poezją awangardową. (...) Musi bowiem brzmieć swojsko, musi reprezentować obiegowe pomysły poetyckie, które przeciętny odbiorca reklamy nauczył się już za poetyckie uważać; musi być swoistym folklorem poezji” (tamże, s. 370). Opinie eksponujące poetyckie walory reklamy pojawiają się bardzo często w wypowiedziach na jej temat - por. na przykład ujęcie E. Szczęsnej, łudząco przypominające cytowane wcześniej słowa Spitzera, co może świadczyć zarówno o nieświadomym zapożyczeniu, jak i o obiegowym charakterze głoszonego sądu: „Oto bowiem handel zaczyna uciekać się do środków poetyckich i poetyckiego obrazowania, doceniwszy ich magiczną siłę we współczesnym, odartym z poezji świecie" (E. Szczęsna, Reklama - sztuka czy perswazja?, „Dialog” 1992, nr 11, s. 72).

${ }^{14}$ L. Spitzer, dz. cyt., s. 338, 339. Literaturocentryczne nastawienie Spitzera przejawia się na różne sposoby. Badacz przy interpretacji reklamy odwołuje się nie tylko do poezji i chwytów w niej zadomowionych, ale także do szerzej pojętego literackiego zaplecza, przywołując przy analizie kompozycji graficzno-tekstowej tradycję szesnastowiecznej i późniejszej literatury emblematycznej, barokowych précieux oraz takich stylów, jak marinizm, gongoryzm, eufizm, Schwulst (co nie znaczy, że nie wykorzystuje odwołań do sztuk wizualnych, czyni je jednak szerszym, a nie podstawowym kontekstem - por. tamże, s. 351).

15 Zob. G. Dorfles, Reklama: retoryka a semantyka, tłum. T. Jekiel [w:] tegoż, Cztowiek zwielokrotniony, tłum. T. Jekiel, I. Wojnar, przedmowa I. Wojnar, Warszawa 1973, s. 233-255. Por. też na przykład A.A. Szablowska, Relacje sztuki i reklamy [w:] Tadeusz Gronowski. Sztuka plakatu i reklamy, Warszawa 2005, s. 56-59.

${ }^{16}$ Na polskim gruncie zob. na przykład M. Głowiński, Poetyka wobec tekstów nieliterackich [w:] Prace wybrane, red. R. Nycz, t. 2: Narracje literackie i nieliterackie, Kraków 1997, s. 229230: „Osobna sfera dociekań to różne formy piśmiennictwa użytkowego i popularnego. Niekiedy nie różnią się one strukturalnie od form tzw. literatury wysokiej i wówczas nie wymagają innych metod analizy niż te, jakie się stosuje wówczas, gdy mowa o pisarstwie należącym do tego właśnie kręgu. Ale w grę tu wchodzą typy wypowiedzi (czy „gatunki mowy”), które w obrębie literatury tak czy inaczej pojmowanej nie funkcjonują, by wymienić różnego rodzaju formuły reklamowe, napisy, porady itp.”. Por. też W. Tomasik, Wakacje na Wyspach Bahama (o perswazji socrealistycznej - dopowiedzenie) [w:] Rozgrywanie światów. Formy perswazji w kulturze wspótczesnej, red. I. Iwasiów, J. Madejski, Szczecin 1994, s. 125-135; M. Płachecki, Pragmatyka plakatu pierwszomajowego (1945-1970) [w:] Spoteczne funkcje tekstów literackich i paraliterackich, red. S. Żółkiewski, M. Hopfinger, K. Rudzińska, Wrocław 1974, s. 79-98 (zwłaszcza s. 82,97$)$. Traktowanie reklamy jako zjawiska odrębnego od wypowiedzi literackiej uwidacznia 
badań nad reklamą narzędzi literaturoznawczych, przede wszystkim z zakresu poetyki (na polskim gruncie konsekwentnie postępuje tak między innymi Ewa Szczęsna ${ }^{17}$ ), albo posiłkowania się metodologiami ukształtowanymi z myślą o analizie utworów literackich (na przykład kluczem do rozumienia zjawisk reklamowych Ignacy Stanisław Fiut czyni kategorie Ingardenowskie ${ }^{18}$ ). W sposób wymowny rzecz ujmował Janusz Sławiński w 1975 roku w artykule wstępnym do monograficznego numeru „Tekstów”, poświęconego formom użytkowym:

literaturoznawcy coraz bardziej zainteresowanym okiem spoglądają na dziedziny komunikatów znacznie luźniej związane z praktykami literatury pięknej. Pociągają ich rozległe obszary tzw. tekstów użytkowych (...), związanych z różnymi wymiarami zwłaszcza współczesnej codzienności: gazetowych, dydaktycznych, reklamowych, propagandowych, epistolograficznych, obwieszczeń, poradników itp., itd.

się też w pracach, w których ta kwestia nie stanowi przedmiotu osobnego namysłu - por. na przykład M. Głowiński, A. Okopień-Sławińska, J. Sławiński, Zarys teorii literatury, wyd. 6 popr., Warszawa 1991, s. 94: „wypowiedzi literackie (...) odznaczają się takimi właściwościami, które w tekstach powstałych w obrębie działania innych stylów społecznych nie występują. Można tu wskazać na takie zjawiska jak budowa wersyfikacyjna, które w zasadzie - z małymi wyjątkami (np. hasła reklamowe, teksty mnemotechniczne) - nie pojawiają się poza wypowiedziami literackimi”. Mam oczywiście świadomość, że przy porównywaniu ze sobą różnych wypowiedzi znaczenie mogą mieć data ich powstania oraz intencja im towarzysząca i pierwotny kontekst ich funkcjonowania. Jeśli jednak decyduję się przywoływać je synchronicznie, to dlatego, że wychodzę z założenia, iż dzieli je w sumie niewielki dystans czasowy. Nie ma on w każdym razie większego znaczenia dla mojego wywodu. Chodzi mi bowiem o zderzenie powstałych niezależnie od siebie oraz niezależnie od kulturowego kontekstu reprezentatywnych stanowisk zajmowanych w kwestii reklamy, które nadal zyskują swoich rzeczników; ponadto wydaje się, że z wielu dawniej sformułowanych tez badacze i krytycy wcale się nie wycofują, o czym pośrednio świadczą ich decyzje o przedrukach prac w niezmienionym brzmieniu. Nie wdając się w drobiazgowe rozważania, warto jednak w tym miejscu podkreślić generalną tendencję w ujęciach reklamy, która może umknąć przy zestawianiu ze sobą prac z różnych lat, a mianowicie to, iż systematycznie przyrasta opinii komentatorów skłonnych rozpatrywać reklamę w kategoriach sztuki (w tym również zjawiska literackiego). Na polskim gruncie jest to o tyle zrozumiałe, że powojenna rzeczywistość z pewnością długo nie sprzyjała wnikaniu w specyfikę reklam, czynieniu jej uprzywilejowanym obiektem namysłu, a tym bardziej dostrzeganiu jej artystycznych walorów.

17 Zob. zwłaszcza E. Szczęsna, Poetyka reklamy, Warszawa 2001. Por. także inne prace tej badaczki: taż, Reklama - sztuka czy perswazja?, dz. cyt., s. 70-81; taż, Reklama - pastisz i metateza, czyli... „dwa w jednym” [w:] Ostrożnie z literatura! (przyktady, wyktady oraz inne rady), red. S. Balbus, W. Bolecki, Warszawa 2000, s. 212-221; taż, Opowiadanie i media, „Pamiętnik Literacki” 2002, z. 2, s. 125-136; taż, Aforyzm a slogan-jezyk jako zdarzenie fikcji, „Teksty Drugie" 2004, nr 1/2, s. 252-266; taż, Narracja jako chwyt tekstowy [w:] Opowiadanie w perspektywie badań porównawczych, red. Z. Mitosek, Kraków 2004, s. 251-266; taż, Poetyka mediów. Polisemiotycznośc, digitalizacja, reklama, Warszawa 2007.

${ }_{18}$ I.S. Fiut, Rozważania o utworze reklamowym, „Zeszyty Prasoznawcze” 1993, nr 3-4, s. 5-15. Zob. też A. Główczewski, „Oddaje tobie, co kryje w sobie”. Uwagi o semantyce przekazu reklamowego [w:] W przestrzeni komunikacyjnej. Szkice z historii i teorii dramatu, teatru i komunikacji spotecznej, red. J. Skuczyński, Toruń 1999, s. 260. 
Co tam pragnęliby znaleźć? Zrozumiałe, że teksty owe wydają się im zajmujące o tyle, o ile dadzą się usytuować w mniej czy bardziej uchwytnej relacji do świata literatury. Ten bowiem zawsze - choćby tylko jako ukryty układ odniesienia wchodzić musi w skład literaturoznawczego przedmiotu. Usiłują więc - często uciekając się do środków przymusu - opisywać własności morfologiczne i tryby funkcjonowania tekstów użytkowych w sposób zakładający ich przynależność do jakiejś sfery „przyliterackiej”.

Stosunkowo najbliższe problematyce dobrze już oswojonej przez historię i teorię literatury są rozważania tyczące powiązań genetycznych i funkcjonalnych - literatury i form piśmiennictwa użytkowego. (...) Inny rejestr wchodzącej w grę problematyki to dziedzina analogii strukturalnych. Blok korespondencji, w którym odkrywa się architekturę powieściową, slogan reklamowy rozważany jako swoisty epigramat poetycki, książka kucharska analizowana tak, jak gdyby była esejem lub cyklem poematów - w każdym wypadku mamy do czynienia z ustaleniem pewnego izomorfizmu między sferami nieprzyległymi. Czyli - z metaforą interpretacyjną. Ale nawet wówczas, gdy badacz literatury nie próbuje ustalać ani zależności genetycznych i funkcjonalnych, ani analogii strukturalnych między tekstami użytkowymi a literaturą, gdy stara się pozostawić owe teksty w ich własnej („naturalnej”) sytuacji komunikacyjnej i w odniesieniu do niej wytłumaczyć ich prawidła morfologiczne i znaczeniowe - wtedy również wyobrażenia związane z literaturą interweniują w jego działania. Same narzędzia analizy i interpretacji, którymi się posiłkuje, przerabiają mu, niezależnie od powziętego zamiaru, materiał podlegający badaniu - w kruszec literacki. Pracują jakby samoczynnie w sposób wyznaczony przez ich dotychczasowe zastosowania. Poetyka pozostaje poetyką nawet w przebraniu terminologicznym semiologii ogólnej. Instrument badawczy - siłą swego bezwładu, ale i sprawności! - zmusza tekst użytkowy do uległości wobec lektury literackiej [wyróżn. autora].

Być może do tego sprowadza się zasadniczy sens charakteryzowanych tu poczynań: kształtują naszą czytelniczą wrażliwość (i podejrzliwość) na literaturę żyjącą poza literaturą ${ }^{19}$.

Chociaż w dokonywanych zwłaszcza w kręgach literaturoznawczych próbach poszukiwania paralel między literaturą a reklamą można dostrzec chęć zamanifestowania oryginalnego podejścia do samozwańczo ukonstytuowanego przedmiotu badań, trudno sprowadzać wszystkie takie starania tylko do wiary w omnipotencję lektury literackiej aplikowanej do ekspansywnych technik komunikacyjnych i różnych nośnych zjawisk kulturowych. Można założyć, że i w samej reklamie (między innymi w jej tworzywowych uwarunkowaniach) i w sposobach jej funkcjonowania jest coś, co skłania do rozpa-

19 J. Sławiński, Jedno z poruszeń w przedmiocie [w:] Prace wybrane Janusza Stawińskiego, red. W. Bolecki, t. 3: Teksty i teksty, Kraków 2000, s. 64-65 (lub pierwodruk: „Teksty” 1975, nr 4, s. 4-5). 
trywania jej w horyzoncie literackim. Tym bardziej że nawet w głosach dystansujących się wobec takiego stanowiska tkwią przesłanki, by sprawy nie bagatelizować, na przykład Anna Nasiłowska, mimo że nie zgadza się na całkowite zrównanie reklamy z literaturą, upatruje głębokich powinowactw między tymi przekazami:

Granica między literaturą a reklamą jest jednocześnie mniej uchwytna, ale i dużo ostrzej zakreślona. Nigdy żadnego hasła nie uznano za samorodny poemat, choć oczywiste jest, że mogą konkurować pod względem perfekcji, metafory, ekspresji językowej. Od czasu romantyzmu przedmiot w utworze poetyckim traci coraz bardziej związek z poświadczoną kodem kulturowym symboliką, zbliżenie się do niego staje się aktem magicznym, odsłaniającym nieznaną stronę duchowości. Czy jednak któremukolwiek z poetów udało się stworzyć magię przedmiotów dorównującą wizji, która jest codziennością reklamy? Reklama to poniekąd dzika magia posługująca się bezbłędnie chwytami poetyckimi ${ }^{20}$.

Symptomatyczne również, że Edward Balcerzan, stanowczo przeciwstawiając się tendencji do odczytywania form użytkowych przez pryzmat kodów wysokoartystycznych, nie neguje tego, iż pewne zabiegi mogą być wspólne rozmaitym tekstom. Jak pisze, konkretne rozwiązania obecne w utworach literackich - takich jak choćby Pamiętnik z powstania warszawskiego Mirona Białoszewskiego czy Traktat poetycki Czesława Miłosza - wkalkulowujących w swoje funkcjonowanie możliwość podwójnej lektury (jako dzieła sztuki i jako dokumentu osobistego lub historycznego) w dużej mierze

prowokowały nie tak dawno literaturoznawców do tego, by w użytkowych dokumentach piśmiennictwa, takich jak reklama, hasła kibiców sportowych, kącik porad sercowych, a nawet książka kucharska poszukiwać elementów poetyki literackiej (...). Elementy takie można, owszem, wskazać (reklama piwa: „maj, czerwiec, Żywiec" korzysta z najlepszych wzorców poezji lingwistycznej!); gorzej jednak z całościowym systemem modelującym, gdyż wyjaśnianie zjawisk mniej skomplikowanych przy pomocy zjawisk bardziej skomplikowanych (literatura artystyczna) to błąd na pewno dydaktyczny, w istocie także metodologiczny ${ }^{21}$.

${ }^{20}$ A. Nasiłowska, dz. cyt., s. 142.

${ }^{21}$ E. Balcerzan, Nowe formy w pisarstwie i wynikające stad porozumienia [w:] Humanistyka przetomu wieków, red. J. Kozielecki, Warszawa 1999, s. 375. Podobne ujęcie prezentował na przykład G. Dorfles, dz. cyt., s. 245-246: „Podczas gdy w poezji zdobnictwo »semantyczne" może się przyczynić do wzrostu wartości estetycznej utworu; podczas gdy w utworze poetyckim nawet elementy »brzmienia" mogą znaleźć skuteczne zastosowanie (czyniąc tekst mniej zrozumiałym, zaciemniając go, co znajduje uzasadnienie w świetle teorii informacji), to w obrazie reklamowym zastosowanie brzmienia lub słownictwa nie może mieć celu »estetycznego", ale wyłącznie służyć zwiększeniu »siły natarcia», dlatego oryginalność informacji, zawsze pożądana w sztuce, tu może się okazać nieproduktywna, a zdobnictwo stylistyczne może przesłonić obraz 
Ten sam argument, jak pokazuje praktyka interpretacyjna, można jednak wykorzystać do udowodnienia tezy o przeciwstawnej wymowie. To, co dla Balcerzana stanowi znak uzależnienia reklamy od chwytów literackich, dla wielu badaczy dowodzi jej emancypacji i uzyskania przez nią statusu niezależnej formy artystycznej, zdolnej do produkowania specyficznych dla siebie znaczeń, niekoniecznie nawet $\mathrm{w}$ sensie formalnym $\mathrm{w}$ pełni oryginalnych, ale przez zmianę kontekstu funkcjonowania na tyle swoistych, że stwarzających podstawy do wyróżnienia zjawiska o odrębnej estetyce:

Reklama wytwarza środek artystyczny, który nazwać by można eklektyczną identyfikacją lub przenikaniem, który z porównania przejmuje fakt zewnętrznego zestawiania, zbliżania elementów i sugerowania ich podobieństwa pod jakimś względem, z metafory zaś element przenoszenia cech - przy czym jest to przenoszenie interpretowane jako przenikanie i wzajemne oddziaływanie bytów o różnym charakterze istotności. (...) Słowo reklamowe jest synkretycznym pastiszem słowa adialogicznego i dialogizującego, estetyzującego i perswazyjnego. W słowie reklamowym przenikają się odmienne postaci słowa, ich ontologie ulegają permutacji. I tak na przykład słowo reklamowe perswaduje estetyką i na odwrót: specyfika tego słowa nie pozwala nie uznać perswazji za kategorię estetyki słowa reklamowego. Wypowiedź reklamowa zaciera granice między estetyzmem i nakłanianiem, narzędziem perswazji czyni poetyckość komunikatu. Posługuje się cudzą mową zwłaszcza mową poezji lingwistycznej, nobilituje słowo reklamowe do rangi słowa poetyckiego, wprowadzając je tym samym w krąg wielkiej sztuki. Operowanie metaforą, peryfrazą, synekdochą równocześnie czyni z niego słowo metafizyczne. Wypowiedź reklamowa łączy to, co ontologicznie sprzeczne - realizm konkretu, doświadczalność przedmiotu użytkowego z językiem metafizycznym, wymykającym się rygorom empiriii ${ }^{22}$.

Nie jest moim celem wpisywanie się w spór o status rozwiązań stosowanych w reklamie, tym bardziej że z góry wiadomo, iż nie doprowadzi on do jednoznacznych rozstrzygnięć (podobnie jak wiadomo, że nie będzie konsen-

i tym samym szkodzić skuteczności jego oddziaływania. Weźmy najprostszy przykład: jeśli w jakimś wierszu zastosuje się dużą ilość przymiotników, dzięki czemu samo pojęcie wzbogacane jest różnymi, analogicznymi przymiotnikami (których przydatność z punktu widzenia semantyki jest wątpliwa), nie wyklucza to faktu, że wiersz ten może mieć wysokie wartości poetyckie; w reklamie zaś można się uciec do powtórzenia słów (lub obrazów) tylko wówczas, jeśli zabieg ten nie umniejszy bodźców percepcyjnych".

${ }^{22}$ E. Szczęsna, Reklama - pastisz i metateza czyli... „dwa w jednym”, dz. cyt., s. 214. Mniej radykalne ujęcie ta sama autorka prezentuje w swojej późniejszej pracy, zob. taż, Poetyka rekla$m y$, dz. cyt., s. 119: „Rozbijanie stałych związków frazeologicznych, wywodzenie z nich metafor wchodzących w grę z utrwalonymi znaczeniami stałych związków, daje też efekt "odświeżenia» języka, jego remetaforyzacji, ukazując reklamę jako pastisz poezji lingwistycznej" [oba wyróżn. autorki]. 
susu przy ustalaniu normatywnej i restrykcyjnej definicji reklamy). Dochodzi dziś zresztą do starcia racji bez wysuwania diametralnie innych argumentów; komentatorzy wyciągają bowiem często jedynie odmienne wnioski z podobnych obserwacji, co więcej mówi o ich założeniach i postawach metodologicznych oraz poglądach odnośnie do kulturowych hierarchii niż o istocie charakteryzowanego fenomenu. W tej sytuacji zaakceptowanie lub bezwzględne odrzucenie któregoś ze spolaryzowanych stanowisk na jego temat nie wydaje się płodne poznawczo. Dlatego zdecydowanie lepiej przyjąć postawę rekonstruktora niż normatywnego interpretatora i poszukać odpowiedzi na pytanie nie tyle o to, czy i pod jakimi warunkami reklama spełnia wymogi dzieła literackiego (tworu artystycznego), ile o to, kiedy dochodzi do jej utożsamiania ze sztuką słowa (lub sztuką w ogóle ${ }^{23}$ ) i jakie argumenty wysuwa się na poparcie tej tezy; innymi słowy: za sprawą jakich właściwości i czynników reklama bywa rozpatrywana w kategoriach literackich (czy szerzej: artystycznych).

Do eksponowania literackich walorów reklamy często prowokują badaczy powinowactwa formalne - takie jak epickość, fabularność, narracyjność, specyficznie zorganizowany językowy kształt przekazu, obecność różnorakich chwytów i tropów semantycznych, wyznaczniki stylistyczne. Przy tego rodzaju podejściu nietrudno spotkać się z opinią, że „każda fabularyzowana forma przekazu reklamowego jest fikcją literacką" ${ }^{24}$, albo hołdować założeniu, że „Poetyckość (...) bywa także chwytem konstrukcyjnym bądź językowym części reklam, zwłaszcza telewizyjnych"25, czy pokazywać, jak formuły reklamowe zamieniają się w „liryczny okrzyk”, „epickie wezwania”, „scenki dramatyczne”26.

${ }^{23} \mathrm{Na}$ ten temat zob. między innymi J. Gibbons, Art and Advertising, London-New York 2005. Na polskim gruncie tej problematyce poświęcił osobne rozważania A. Kisielewski, Sztuka i reklama. Relacje między sztuka i kultura, Białystok 1999; zob. też tenże, Poetyka obrazu reklamowego [w:] Ekspansja obrazów. Sztuka i media w świecie wspótczesnym, red. B. Frydryczak, Zielona Góra-Warszawa 2000, s. 55-63. Por. też: W. Lipowicz, Zysk i powinność. Dzieto sztuki $w$ polskiej reklamie turystycznej $w$ latach trzydziestych [w:] Sztuka dwudziestolecia międzywojennego. Materiaty Stowarzyszenia Historyków Sztuki, Warszawa, październik 1980, red. A. Marczak, Warszawa 1982, s. 137-153; A. Radajewski, Sztuka reklamy - reklama sztuki, „Kierunki” 1987 nr 15; I.S. Fiut, dz. cyt., s. 5-15; R. Arnold, Just do it! Nike jako sztuka publiczna, tłum. M.K. Wasilewski, „Czas Kultury” 1999, nr 3-4, s. 20-23; P. Derda, Billboard-wytwór kultury masowej czy dzieto sztuki? (Uwagi optymisty), „Kultura Współczesna” 2000, nr 3, s. 54 66; M. Krajewski, Zamiast sztuki - zamiast reklamy [w:] Publiczna przestrzeń dla sztuki?, red. M.A. Potocka, Kraków-Wiedeń 2003, s. 155-165. Por. też zapis debaty Sztuka reklamy? [dyskusja z udziałem J. Dybczyńskiego, K. Jakubowicza, M. Janickiego, J. Witkowskiego, D.J. Cirlić], „Dialog” 1992, nr 11, s. 82-89 oraz artykuły zgromadzone w pracy zbiorowej Estetyka reklamy, red. M. Ostrowicki, Kraków 2002 (tu zwłaszcza: A. Kisielewski, Reklama - sztuka czy ikonosfera?, s. 53-60; I. Czudowska-Kandyba, Czy reklamę można rozpatrywać jako sztukę?, s. 79-82).

${ }^{24}$ L. Stafiej, Manipulo, „Impact” 1999, nr 1, s. 62.

25 G. Majkowska, dz. cyt., s. 322.

26 P. Bogatyriew, Okrzyki przekupniów ulicznych i wędrownych rzemieślników - znaki rekla$m y$, tłum. I. Szymanowska [w:] Semiotyka kultury ludowej, wstęp, wybór i oprac. M.R. Mayenowa, Warszawa 1979, s. 302. 
Znawcy zagadnienia akcentują, że reklama „konstytuuje metaforyczne epitety eklektyczne"27, obfituje w „metafory transsemiotyczne, epitety, hiperbole”28, zaś „Przedmiot w reklamie często poddany jest antropomorfizacji”" ${ }^{29}$, albo że „Przekaz reklamowy jawi się jako wszechogarniający pastisz”30.

Pokusa, by widzieć w konkretnych reklamach przejawy sztuki, niewątpliwie wzmaga się również wtedy, gdy ich realizatorami stają się artyści, zwłaszcza o rozpoznawalnej twórczości, a często też o niekwestionowanej randze. Reklamy mają w swoim dorobku liczni przedstawiciele sztuk plastycznych, między innymi: Alfons Mucha, Aleksander Rodczenko, El Lissitzky, Salvador Dali, René Magritte, Andy Warhol, Keith Haring, ponadto tacy reżyserzy filmowi, jak choćby Federico Fellini, Carlos Saura, Jean-Luc Godard, David Lynch, Jean Jaques Annaud, Ridley Scott, Roman Polański, Agnieszka Holland czy Krzysztof Krauze, a także twórcy związani z teatrem - na polskim gruncie takiego zadania podjął się na przykład Grzegorz Jarzyna ${ }^{31}$. Wśród autorów reklam znaczącą grupę stanowią też literaci, sukcesy w tej dziedzinie odnosili między innymi: Emil Zola, Włodzimierz Majakowski czy Melchior Wańkowicz. Warto przy okazji odnotować, że wśród zajęć, którym oddają się pisarze (i to zarówno z powodów wyłącznie zarobkowych, jak i z pobudek artystycznych, z chęci realizacji programów i postulatów twórczych oraz z potrzeby nabywania nowych doświadczeń i poszerzania eksploracji estetycznych), systematycznie rośnie od końca XIX wieku znaczenie usług copywritera ${ }^{32}$. Ważne

27 E. Szczęsna, Reklama - pastisz i metateza czyli... „dwa w jednym”, dz. cyt., s. 217.

${ }^{28}$ Hasło: Reklama [w:] Stownik pojęć i tekstów kultury. Terytoria stowa, red. E. Szczęsna, wyd. 3 popr., Warszawa 2002, s. 242.

29 Tamże. Por. też na przykład E. Szczęsna, Reklama - pastisz i metateza czyli... „dwa w jednym”, dz. cyt., s. 216-217.

30 E. Szczęsna, Reklama - pastisz i metateza czyli... „dwa w jednym”, dz. cyt., s. 212.

31 Por. na przykład notkę prasową: K. Lubelska, Jarzyna w reklamie, „Polityka” 2004, $\mathrm{nr} 21$, s. 69. Osobnym zjawiskiem są zaplanowane akcje artystyczne wspierające kampanie reklamowe konkretnych firm. W takich działaniach celuje chociażby producent wódki Absolut, której reklamy zamawiane są u uznanych plastyków z całego świata, wykonujących je w rozpoznawalnych dla siebie stylach (jedynym warunkiem reklamodawcy jest umieszczenie na plakacie kształtu butelki promowanego trunku), a następnie - oprócz odsłon prasowych i billboardowych - prezentowane są na wystawach objazdowych (na ten temat zob. na przykład M.A. Potocka, Absolut Art Collection, „Odra” 1998, nr 5, s. 146-148; por. też N. Ind, Wódka Absolut, Stany Zjednoczone. Absolutna doskonatość. Kampania prasowa z lat 80. [w:] Wielkie kampanie reklamowe, tłum. M. Jóźwicka, Warszawa 2001, s. 17-33, zwłaszcza s. 22).

${ }^{32}$ Owocuje to też konstatacjami w stylu: „Cóż, Shakespeare, gdyby dzisiaj żył, pisałby teksty do reklam. Dla chleba, oczywiście" (K. Jakubowicz - głos w dyskusji, Sztuka reklamy?, dz. cyt., s. 89; por. M. Wroński, Gdyby Mickiewicz byt copywriterem..., „AIDA Media” 1998, nr 6, s. 34-36). Zob. też P. Dunin-Wąsowicz, Bystrzy dyletanci, „Lampa” 2005, nr 1, s. 38-40. Warto odnotować, że od XX wieku przyrasta tekstów literackich, których tematem stają się perypetie i rozterki twórców podejmujących pracę w branży reklamowej, co bywa traktowane jako zdrada ideałów lub objaw degradacji roli artysty w kulturze, a także jako - wprost przeciwnie możliwość artystycznej samorealizacji. 
jest przy tym, jaką rangę tej sferze swojej działalności nadają sami twórcy, jak definiują swoją profesję we wskazanym obszarze, jakie miejsce zajmuje ona w ich całym dorobku, czy i ewentualnie w jakim stopniu skłonni są widzieć w niej znamiona działalności artystycznej.

Zwolennicy tezy o zrównaniu reklamy ze sztuką zwracają uwagę również na kwestię kontekstu funkcjonowania poszczególnych przekazów, przyjmując, że zmiana owego kontekstu (lub sama podatność na jego modyfikację) może wzmacniać tezę o zdolności tej formy komunikowania do nabierania cech sztuki. Chodzi przede wszystkim o przypadek, gdy reklama, oderwana od typowej dla siebie funkcji perswazyjnej czy czysto handlowej, zaczyna sytuować się w porządku zjawisk artystycznych, co w wypadku reklam o nacechowaniu wizualnym następuje na przykład wówczas, kiedy umieszcza się je w muzeach i galeriach sztuki ${ }^{33}$ albo gromadzi ich reprodukcje w albumach, często obok innych dzieł o niekwestionowanej estetycznej wymowie ${ }^{34}$; a w wypadku spotów reklamowych, gdy wyświetla się je w stężonej dawce na specjalnych seansach kinowych czy festiwalach artystycznych, kładąc nacisk na ich oddziaływanie estetyczne. Per analogiam można by rzec, że podobny efekt dałoby się uzyskać - przynajmniej hipotetycznie - przez ulokowanie reklam o bezsprzecznych walorach językowych w wydaniach książkowych wśród utworów poetyckich lub $\mathrm{w}$ specjalnych antologiach $\mathrm{w}$ całości wypełnionych przekazami pozbawionymi swojej funkcji utylitarnej, których odbiór ma się odbywać w warunkach analogicznych do lektury dzieł literackich. Taki efekt wzmaga się, jeśli odbiorca obcuje z reklamami, które utraciły swój użytkowy charakter, gdyż rekomendowane przez nie produkty bądź usługi przestały istniećc ${ }^{35}$. Jednak nawet w odniesieniu do komunikatów propagujących dobra, które ciągle są szeroko dostępne, istnieje możliwość zawieszenia perswazyjnych elementów przekazów poprzez umieszczenie ich w niehandlowych ramach i nadanie im funkcji estetycznych. Jest zresztą w takim postępowaniu dekontekstualizacyjnym analogia do sposobu, w jaki dochodzi dziś do włączania w sferę artystyczną rozmaitych obiektów i działań. W myśl zaakceptowanych obecnie reguł sztuką niejednokrotnie staje się to, co zaistnieje w jej obszarze na mocy

33 Organizowanie wystaw eksponujących artystyczne walory reklam ma długą tradycję, o odbywającej się w Amsterdamie w 1917 roku wystawie Art in Advertising wspomina D. Bernstein, Sztuka a reklama [w:] tegoż, Billboard - reklama otwartej przestrzeni, tłum. E. Ciszkowska, Warszawa 2005, s. 20.

34 Por. na przykład katalogi czy albumy: M. Czubińska, Polski plakat secesyjny ze zbiorów Muzeum Narodowego w Krakowie, Kraków 2003; Nie tylko plakat. Polska grafika reklamowa Dwudziestolecia, koncepcja, wybór i oprac. tekstów T. Lachowski, [b.m.] 2003; Permanentny remanent. Polska grafika reklamowa w czasach PRL-u, koncepcja, wybór i oprac. tekstów T. Lachowski, [b.m.] 2006. Na taki aspekt ujmowania reklamy wskazywała też między innymi E. Szczęsna, Reklama-sztuka czy perswazja?, dz. cyt., s. 70, 81. Por. też na przykład P. Derda, dz. cyt., s. 63-66.

35 Por. na przykład B. Lisowska, Urok nieaktualności. Ikonosfera malowanych reklam ściennych, „Kultura Współczesna” 2002, nr 3-4, s. 65-70. 
wskazania lub uruchomionych procedur instytucjonalnych - o sytuowaniu w porządku estetycznym konkretnych wytworów rozstrzygają zatem niejednokrotnie autorytet i indywidualna decyzja artysty, a często też kuratora, krytyka, redaktora czy antologisty, względnie grupy odbiorców, którzy na mocy rozmaicie artykułowanego porozumienia osiągają consensus względem obiektów własnej kontemplacji estetycznej.

Ponadto o dostrzeganiu w reklamie znamion sztuki mogą przesądzać częstokroć motywacje towarzyszące powstaniu konkretnych komunikatów, a także zakładana lub realna siła ich oddziaływania. Ilustruje to dobrze przykład strategii stosowanej przez Oliviera Toscaniego, swego czasu autora kontrowersyjnych - i przez to dobrze zapamiętywanych - reklam dla włoskiej firmy odzieżowej Benetton, który czuje się pełnoprawnym artystą i postrzega własną działalność w kategoriach jednocześnie aktywności twórczej oraz misji, tak definiując swoje intencje i w ogóle stawiane reklamie cele:

W moich reklamach dążyłem do dialogu z opinią publiczną o potędze uprzedzeń i stereotypów (bo przecież reklama aż pęka od nich). O uległości i wolności ducha. O tolerancji. (...) Dlaczego reklama, tak jak sztuka lub media, nie może być polem gry dla filozofii, katalizatorem emocji, terenem sporu i polemiki? (...) ja nie uprawiam reklamy. Nie sprzedaję towaru. Nie staram się za pomocą trywialnych trików namawiać kogokolwiek do robienia zakupów. (...) Nie jestem cyniczny, poszukuję nowych środków wyrazu. Dyskutuję z publicznością, jak inni artyści. (...) Wykorzystuję możliwości reklamy - pogardzanej i niewyzyskanej sztuki, jej siłę oddziaływania i zdolność prezentacji. Drapię opinię publiczną tam, gdzie ją swędzi. Uczestniczę w publicznej debacie, podobnie jak pisarz, jak pamflecista, jak dziennikarz ${ }^{36}$.

Jak widać, reklama może awansować do rangi dzieła sztuki, gdy przypisze się jej od dawna przynależne mu zadania. Abstrahując w tym momencie od kontrowersji, które wywołuje postawa Toscaniego (głównie ze względu na swój radykalizm, utopijność, a niekiedy również naiwność założeń) ${ }^{37}$, warto

36 O. Toscani, Reklama uśmiechnięte ścierwo, tłum. M. Misiorny, [b.m.] [b.r.], s. 46, 87. Podobne deklaracje osłabiają jednak stwierdzenia wplatane w tego rodzaju wypowiedzi: „Nie będę zachwalał wzorów i barw pulowerów Benettona, ponieważ tak jak wszyscy jestem przekonany o ich wysokiej jakości" (tamże, s. 87).

${ }^{37} \mathrm{Na}$ temat strategii Toscaniego zob. między innymi: A. Muszyński, Przypadek Benetto$n a$ [w:] Mitologie popularne. Szkice z antropologii wspótczesności, red. D. Czaja, Kraków 1994, s. 159-164; M. Bratkowska, Kolory życia do wynajęcia, „Magazyn Gazety Wyborczej” 1997, nr 32, dod. do „Gazety Wyborczej” 1997, nr 184, s. 16-17; P. Derda, dz. cyt., s. 54-66 (zwłaszcza s. 58-63); J. Bond, R. Kirshenbaum, Oszukać radar. Jak mówić do konsumenta, który nie chce stuchać, tłum. M. Wajda, Warszawa 2001, s. 127-128; A. Cichocka, Szok - metoda na rekla$m e($ ?) [w:] Estetyka reklamy, dz. cyt., s. 319-324; M. Kochan, Toscani [w:] tegoż, Slogany w reklamie i polityce, Warszawa 2005, s. 224-231; A. Pomieciński, Reklama w kulturze wspótczesnej. Studium antropologiczne, Poznań 2005, s. 29-31; E. Musiałowska, Reklama w komunikacji 
podkreślić, że taka generalna - najczęściej jednak w mniej wyostrzonym wariancie - linia rozumowania jest bliska tym diagnostom reklamy, którzy uwypuklają społeczny wymiar zjawiska, podkreślając, że skutecznie zagospodarowuje ono rejony często dobrowolnie przez sztukę współczesną zarzucone ${ }^{38}$ :

Reklama zbliża się do sztuki zwłaszcza w swej funkcji zagospodarowywania wyobraźni i ukierunkowywania marzeń. Niegdysiejszym pokoleniom „Judymów” czy „Siłaczek” odpowiadają dziś pokolenia „2000” lub „Frugo”; w ten sposób reklama wślizguje się w miejsce zajmowane przez sztukę, które to miejsce sztuka oddała dobrowolnie, w stanie wyjałowienia będącego nieuchronnym skutkiem długotrwałego procesu jej autonomizacji. Reklama sprawuje dziś niemal niepodzielną władzę w obszarach zbiorowej wyobraźni: kreuje marzenia i zapewnia ich natychmiastową realizację. Wytwarza pozór powiązań dawno utraconych przez sztukę: z magią, mitem, ideologią, ideami i archetypami. Rości sobie pretensje do budowania światopoglądu ${ }^{39}$.

Charakterystyczne, że dostrzegając potęgę reklamy w zakresie kształtowania zbiorowej świadomości i posługiwania się uniwersalnymi kodami komunikacyjnymi, cytowana badaczka pośrednio akcentuje jej umiejętność oddziaływania na zasadach, które bywały kiedyś domeną zwłaszcza społecznych funkcji literatury, zdolnej do opisywania rzeczywistości i wpływania na nią przez tworzenie sugestywnych wizji ${ }^{40}$. O reklamie pisze się nawet, że poprzez

międzykulturowej [w:] Pomiędzy kulturami. Szkice z komunikacji międzykulturowej, red. M. Ratajczak, Wrocław, 2006, s. 159-177. Por. też rec. książki O. Toscaniego Reklama. Uśmiechnięte ścierwo, dz. cyt. - W. Ratajczak, Pulower Wielkiego Brata, czyli Nie po oczach!', „Czas Kultury” 1997, nr 5-6, s. 124-125; oraz wywiady: Moralność obrazu, z O. Toscanim rozm. W. Kocołowski, „Przekrój” 2001, nr 7, s. 10-14; Na Jezusa wpadtem na Siódmej, z O. Toscanim rozm. J. Mikołajewski, „Duży Format” 2002, nr 24, dod. do „Gazety Wyborczej” 2002, nr 243, s. 4-10.

${ }^{38}$ Dobitnie rzecz ujmował G. Elgozy, dz. cyt., s. 85: „W wieku, w którym wszyscy skarżą się na trudności porozumienia - na to nadmiernie klimatyzowane powietrze, w którym żyją (albo zdychaja) literaci i filozofowie - reklama jest jedyną strukturą zdolną zapewnić łączność i symbiozę wszystkich członków tego samego ciała, wszystkich ciał tego samego społeczeństwa. (...) Nawet najbardziej rozwinięta cywilizacja cofa się, skoro tylko przestają w niej krążyć przekazy i wiadomości”.

${ }^{39}$ K. Wilkoszewska, Wprowadzenie [w:] Estetyka reklamy, dz. cyt., s. 8. Jakkolwiek te obserwacje wskazują w intencji autorki na powiązania zachodzące między reklamą a sztuką, daleka jest ona od wydawania jednoznacznego werdyktu i ostatecznie formułuje wyważony wniosek: „Niemniej, nie osiągając wymiaru i głębi dzieł artystycznych, reklamowe dziełka są bliższe w swej funkcji komunikacyjnej raczej propagandzie niż sztuce prawdziwej” (tamże).

${ }^{40}$ Podobnie rzecz ujmuje między innymi J. Bralczyk, kiedy na pytanie o to, „Czy reklama może pretendować do jakiegoś zastępnika literatury? (...) Czy reklama może decydować o tym, jak i co myślimy? Bo przecież często zaczynamy myśleć reklamą. Daje nam ona nie tylko gotowe zbitki słowne, które są wygodne w użyciu, ale również staje się jakby naszą drugą świadomością”, odpowiada: „Reklama rzeczywiście wykorzystuje skrypty kulturowe, społeczne, komunikacyjne, ale też je współtworzy, utrwala i wprowadza do obiegu społecznej komunikacji oraz 
przyrodzony jej „wymiar katarktyczny (...) jest być może bliższa tragedii antycznej niż sztuce masowej. Zatem reklama, jeżeli w ogóle możemy mówić, że jest sztuką, to raczej poprzez swoją funkcję niż poprzez inne cechy, takie jak wartości lub jakości estetyczne czy artystyczne” ${ }^{31}$.

A jednak reklama zaczyna być traktowana w kategoriach sztuki również ze względu na swoje oddziaływanie estetyczne. Jej przynależność do świata form artystycznych legalizuje bowiem nastawienie odbiorców, którzy szukając w reklamie walorów pozahandlowych, niejednokrotnie znajdują ekwiwalenty przeżyć estetycznych:

Jeśli psychologia reklamy mówi o wpływie reklamy na upodobania estetyczne publiczności, to tylko w tym sensie, że reklama propaguje niekiedy przedmioty o walorach artystycznych, przyczyniając się tym samym do estetycznej edukacji społeczeństwa (...). Z drugiej strony przyznaje się (...), że reklama stwarza niekiedy swym adresatom możliwość „zastępczego spełniania pragnień”. Myślę, że te dwie funkcje można rozpatrywać łącznie przyznając, że reklama zaspokaja estetyczne pragnienia dzisiejszych ludził ${ }^{22}$.

Systematycznie poszerza się grono admiratorów reklam, otaczających je bezinteresownym zainteresowaniem czy wręcz kultem, na przykład entuzjaści reklam kolekcjonują ich rozmaite odmiany, odkrywając w nich estetyczny potencjał; stałych bywalców, nierekrutujących się tylko z branży zawodowej, doczekały się też odbywające się cyklicznie festiwale reklamy i inne imprezy docelowo jej poświęcone ${ }^{43}$; również obecność reklam w galeriach czy muzeach w sposób naturalny sprzyja wywoływaniu wśród audytorium doznań estetycznych. Choć ich źródłem stają się przede wszystkim reklamy o walorach wizualnych, nie jest wykluczone, że nie stymulują ich też zawarte w przekazach reklamowych jakości

społecznej świadomości. (...) można nawet mówić o pewnej archetypizacji” (Reklama i okolice. Z Jerzym Bralczykiem rozmawia Jacek Warchala, „Świat i Słowo” 2006, nr 2, s. 24).

${ }_{41}$ M. Ostrowicki, Propaganda przetomu wieków [w:] Estetyka reklamy, dz. cyt., s. 391.

${ }^{42}$ L. Spitzer, dz. cyt., s. 361. Co znamienne, również rzecznicy tezy o niemożności uznania reklamy za sztukę odwołują się do analogicznej argumentacji, na przykład reżyser Jacek Witkowski twierdzi, że „Reklama nigdy nie będzie dziełem sztuki, bo konsument, czyli jej odbiorca, nie podchodzi do niej z nastawieniem estetycznym" (J. Witkowski - głos w dyskusji, Sztuka reklamy?, dz. cyt., s. 86), z czego łatwo wyciągnąć wniosek, iż wyraziciel podobnej opinii skłonny byłby do uznania reklamy za sztukę, gdyby tylko zaobserwował, że odbiorcy zaczynają sytuować ją w porządku zjawisk estetycznych.

${ }^{43}$ Liczne audytorium gromadzą popularne na świecie i w Polsce Noce Reklamożerców, kilkugodzinne, a nawet całonocne seanse kinowe, podczas których prezentowane są filmy reklamowe, zwykle nagrodzone w prestiżowych konkursach i legitymujące się wysokimi walorami warsztatowymi. Ich oglądaniu towarzyszy szczególny rytuał: publiczność wyposażona bywa w specjalne rekwizyty, na przykład w czapeczki i trąbki (ich dźwięk ma sygnalizować pozytywną reakcję na konkretny przekaz), spoty odbierane są zaś analogicznie jak filmy krótkometrażowe w oderwaniu od swoich komercyjnych właściwości, z zastosowaniem zaś kryteriów artystycznych. 
literackie. Jak przekonują konkretne świadectwa, zestetyzowany odbiór komunikatów reklamowych, ujawniających niekiedy nawet iluminacyjno-epifanijny potencjał, może zachodzić w sytuacjach bardzo codziennych:

Wiele lat temu zobaczyłem w pociągu kolei miejskich plakat, który, gdyby rzeczy tego świata toczyły się właściwym torem, znalazłby miłośników, historyków, egzegetów i kopistów - równie licznych, jak to bywa w przypadku każdego wielkiego dzieła poezji czy malarstwa. Jakoż w istocie ów plakat był jednym i drugim. I podobnie, jak to się zdarza, gdy coś niespodziewanie wywiera na nas głębokie wrażenie, przeżyłem wstrząs tak silny, wrażenie - jeśli wolno mi tak powiedzieć - zapadło we mnie tak głęboko, iż przebiło dno świadomości, aby na całe lata skryć się w jakimś ciemnym zakamarku. Wiedziałem tylko, że chodziło o „sól Bullrich” (...). I oto któregoś spłowiałego niedzielnego popołudnia (...) stanąłem (...) przed nędznym szynkiem, którego okno wystawowe ożywiało kilka wywieszek. Jedna z nich zawierała tylko słowa „sól Bullrich” - i raptem wokół tego znaku graficznego ją się bez wysiłku kształtować pustynny krajobraz pierwszego plakatu. (...) Wyglądał tak: na pierwszym planie tej pustyni jechał wóz ciągnięty przez konie. Wyładowany był workami z napisem „sól Bullrich”. Jeden z worków miał dziurę, przez którą sól sypała się na ziemię, gdzie utworzyła już długą wstęgę. Dalej, w głębi pustynnego pejzażu, stały dwa słupy podtrzymujące wielki szyld z napisem „Najlepsza ze wszystkich”. Co jednak robiła owa solna wstęga znacząca drogę wozu przez pustynię? Otóż układała się ona w litery tworzące słowa „sól Bullrich”. Czyż harmonia przedustawna takiego na przykład Leibniza nie była dziecinadą wobec tej arcyprecyzyjnej, pustynnej predestynacji? I czyż plakat ten nie zawierał przypowieści o rzeczach, jakie na tym świecie nikomu się jeszcze nie przytrafity? Przypowieści o dniu powszednim utopii? ${ }^{44}$

Jak widać (również w przywołanym powyżej cytacie z Pasaży Waltera Benjamina), o uznawaniu reklamy za sztukę (w tym też za sztukę słowa) decydują różne czynniki. Prawem résumé warto się pokusić o wypunktowanie wszystkich wskazywanych dotąd argumentów, które mają wpływ na takie kwalifikacje. Do twierdzenia, że reklama może być rozpatrywana w kategoria literatury (sztuki), dochodzi zatem, po pierwsze, w sytuacji gdy legitymuje się ona walorami artystycznymi, korzysta z repertuaru środków wypracowanych przez różne odmiany sztuki i ciągle do nich przynależnych; po drugie, gdy ma ona charakter nieanonimowy, a jej twórcy rekrutują się z grona artystów lub sami chcą tytułować się tym mianem; po trzecie, gdy kontekst i instytucjonalne ramy funkcjonowania konkretnych reklam czynią z nich zjawiska artystyczne; po czwarte, gdy reklama przejmuje zadania tradycyjnie przypisywane sztuce - zwłaszcza w zakresie jej funkcji kreowania postaw społecznych, mitów

${ }^{44}$ W. Benjamin, Wystawiennictwo, reklamy, Grandville [w:] tegoż, Pasaże, red. R. Tiedemann, tłum. I. Kania, Kraków 2005, s. 201-202. 
zbiorowej wyobraźni czy wpływania na obraz rzeczywistości; po piąte, gdy zaczyna ona oddziaływać na odbiorców, stając się dla nich źródłem doznań estetycznych. Oczywiście w praktyce diagnostycznej czy interpretacyjnej te argumenty mogą występować implicite oraz dawać o sobie znać w rozmaitym natężeniu i w różnym splocie (ich separacyjne wyizolowanie ma dla mnie jedynie wymiar poglądowy). O tym, że tak się dzieje, przekonują nawet diagnozy wydawane w trybie literackim: w opowiadaniu Stefana Themersona Hau! Hau!, czyli kto zabit Ryszarda Wagnera leksykalna archaiczność, melodyjność frazy oraz brzmieniowe czy wręcz muzyczne walory ogłoszenia firmy bieliźniarskiej zachwalającej wyprawę ślubną prowokują narratora do uznania tego komunikatu za dzieło poetyckie, gdyż: „Czas przemienia ogłoszenia w poematy i Czas przemienia poematy w ogłoszenia, albowiem Czas przeobraża czytelnika, i to od czytelnika zależy, czy coś jest, czy nie jest sztuką̧" ${ }^{35}$.

Problem nie wyczerpuje się jednak tylko na rekonstrukcji argumentów przemawiających za - nawet czysto hipotetycznie - włączeniem reklamy do form artystycznych. Równie istotne są konsekwencje upowszechniania się takich nastawień w kulturze (jedną z takich konsekwencji - poszerzanie repertuaru tematycznego tekstów literackich o dyskutowaną w nich kwestię literackości i artystyczności reklamy - ilustruje przywołane przed chwilą opowiadanie). Uznawanie reklamy za sztukę nie świadczy jedynie o zmianach w postrzeganiu reklamy, ale wskazuje również na przemiany zachodzące w obrębie sztuki, która coraz częściej z własnej nieprzymuszonej woli sama wychodzi reklamie naprzeciw, stara się różnymi sposobami ją naśladować albo wręcz do niej niewolniczo upodabniać i czynić jednym ze swoich ważnych pozytywnych wzorców. Nieprzypadkowo badacze rozważający problem artystycznych koneksji reklamy stwierdzają, iż „ciekawszy od estetyki samych reklam jest wpływ estetyki reklamy na estetykę w ogóle" ${ }^{\text {46 }}$, albo czują się w obowiązku czynić zastrzeżenie, że „współczesne pojęcie dzieła sztuki dotyczy zupełnie innych obszarów niż w niedawnej przeszłości. (...) Artyści, chcąc mówić o świecie, zaczęli korzystać z dobrodziejstw cywilizacji i techniki, transponując je na swój użytek" ${ }^{37}$.

Zrównywanie reklamy ze sztuką uzmysławia, jak obecnie traktujemy sztukę i jakimi jej definicjami dysponujemy. W opiniach eksponujących artystyczny wymiar reklamy tkwi nie zawsze jawna, ale stosunkowo łatwo uchwytna implikacja, że najbardziej dziś adekwatnym sposobem dookreślania dzieła sztuki jest ujmowanie go $\mathrm{w}$ aspekcie pragmatycznym, komunikacyjnym albo/i socjologicznym ${ }^{48}$. Te zagadnienia doczekały się omówień pod różnym

${ }^{45}$ S. Themerson, Hau! Hau!, czyli kto zabit Ryszarda Wagnera [w:] tegoż, Generat Piesc $i$ inne opowiadania, Warszawa 1980, s. 251.

${ }^{46}$ K. Jakubowicz - głos w dyskusji, Sztuka reklamy?, dz. cyt., s. 85.

47 P. Derda, dz. cyt., s. 63.

48 Przy takim ujęciu dzieło sztuki jawi się przede wszystkim jako komunikat lub/i socjologiczny twór kultury, a nie na przykład „zdwojenie natury” (jak głosi teoria mimetyczna dzieła sztuki), fakt psychiczny (jak chcieliby zwolennicy psychologicznej teorii dzieła sztuki), przed- 
kątem w pracach estetyków, historyków sztuki i kulturoznawców, zajmujących się kondycją sztuki współczesnej, a zwłaszcza statusem sztuk wizualnych. Wydaje się jednak, że analogiczne kwestie nie wybrzmiały wystarczająco $\mathrm{w}$ kontekście stricte literackim. Tymczasem z nakreślonej perspektywy równie ciekawe jak pytanie, co sprawia, że reklama bywa uznawana za literaturę lub sytuowana w horyzoncie jej bliskiego oddziaływania, jest kwestia, jakie moga być następstwa takiej wykładni dla postrzegania i rozumienia sztuki słowa. To podejście mimowolnie mówi przecież także o obowiązujących definicjach literatury i wyznacznikach „literackości”49. Pokazuje, że punkt ciężkości w tych definicjach może być położony na sposób funkcjonowania zjawiska w społecznej świadomości, zasady jego oddziaływania (w bliskim powiązaniu oczywiście z cechami strukturalnymi przekazów). Jednocześnie warto też bliżej przyglądać się, jak reklama, urastająca do rangi sztuki lub chociażby doskonałego rzemiosła, determinuje pozycję literatury w odczuciu odbiorców i w ogóle uczestników kultury oraz jak wpływa na wyłaniające się z utworów literackich sensy i modyfikuje ich globalne przesłania. O tym, że ta kwestia nurtuje w dużej mierze samych pisarzy, przekonuje choćby głos Bogdana Zadury, który wskazuje na szczególną sytuację poezji polskiej powstającej po 1989 roku, biorąc pod uwagę właśnie reklamowy kontekst:

sytuacja twórców i konsumentów poetyckiego słowa uległa w ostatnich paru latach zasadniczej zmianie. Jak mi się zdaje, nikt dotąd nie próbował tej nowej sytuacji opisać.

Nie da się tego zrobić przy pomocy takich pojęć jak obowiązi poety. Poeta jako poeta nie ma żadnych obowiązków, a przynajmniej takich, z których mógłby

miot intencjonalny ( $w$ myśl ustaleń fenomenologów), obiekt idealny czy duchowy, nakierowany ku własnej transcendencji (jak rzecz przedstawiają rzecznicy idealistycznej teorii dzieła sztuki) albo byt autonomiczny (jak ujmowane to jest w różnych wariantach estetyzmu) itp. Odwołuję się tu do klasycznej typologii teorii dzieła sztuki, której przegląd prezentuje między innymi M. Gołaszewska, Teorie dzieta sztuki [w:] tejże, Zarys estetyki. Problematyka, metody, teorie, wyd. 3 uzup., Warszawa 1986, s. 246-278. Komunikacyjną eksplikacją reklamy zajmował się między innymi U. Eco, Komunikat reklamowy, tłum. A. Weinsberg [w:] tegoż, Nieobecna struktu$r a$, tłum. A. Weinsberg, P. Brawo, Warszawa 1996, s. 175-196. Por. też tenże, Komunikat estetyczny, tłum. A. Weinsberg [w:] tegoż, Nieobecna struktura, dz. cyt., s. 79-98.

${ }_{49}$ Wpisuje się to w chętnie również dziś przywoływane słynne rozpoznanie R. Jakobsona, zawarte w jego książce Nowiejszaja ruskaja poezija. Nabrosok pierwy: Podstupy k Chlebnikowu (Najnowsza poezja rosyjska. Szkic pierwszy: w stronę Chlebnikowa; ta pomyślana początkowo jako wstęp do poezji Wielimira Chlebnikowa praca została napisana w roku 1919, a ogłoszona w Pradze w 1921): „Przedmiotem wiedzy o literaturze jest więc nie literatura, lecz literackość, to jest to, co czyni dzieło sztuki literackim" (cyt. wg pol. wersji przekładu: R. Jakobson, Problemy poetyki, tłum. A. Brosz [w:] Teoria badań literackich za granicą. Antologia, red. S. Skwarczyńska, t. 2: Od przetomu antypozytywistycznego do roku 1945, cz. 3: Od formalizmu do strukturalizmu, Kraków 1986, s. 39). Na marginesie warto zasygnalizować, że to założenie aplikował do badań nad reklamą, postulując poszukiwanie swoistych tylko dla niej wyznaczników, A. Kisielewski, Poetyka obrazu reklamowego, dz. cyt., s. 55-63. 
go ktoś (lub cokolwiek) zwolnić. Myślę, że lepiej posłużyć się kategorią roli, jaką poezja spełnia, pożytków, jakie z niej płyną lub płynęły. Z niej i tylko z niej jako ze specyficznego sytemu językowego. Nie da się tu pominąć kwestii znaczenia, znaczenie zaś często (zawsze?) zależy od kontekstu. (...) najważniejszym kontekstem poezji jest kontekst językowy. To on się właśnie zmienił. Jak? Spróbujemy się temu przyjrzeć. (...)

KIEDY PRANIE JEST CZYSTSZE, BIEL JEST BIELSZA, PODARUJ SOBIE ODROBINĘ LUKSUSU. I PAMIĘTAJ, DWA RAZY DZIENNIE. Każde $\mathrm{z}$ tych sformułowań mogłoby być tytułem lub fragmentem jakiegoś wiersza, choć pochodzą one z różnych reklam. Obraz, skojarzenie, skrót myślowy i tu, i tu są pożądane. Różnica polega na tym, że poezja $\mathrm{z}$ wielkim trudem nadaje słowom nowe znaczenia, modyfikując je raczej i wzbogacając, a to przeważnie w obrębie i na użytek swoich własnych, dość hermetycznych struktur. Jeśli jakieś słowo w wierszu znaczy coś innego - coś więcej - niż normalnie, to podstawowe, słownikowe znaczenie i tak pozostaje niewzruszone. Cokolwiek by kto sądził na temat niezrozumialstwa poezji, nie niszczy ona słów. Jeśli jakieś z nich się w niej zużywają, to dzieje się to w przeciągu całych epok, a owo zużycie się, nad którym pracują całe rzesze epigonów, też dotyczy raczej ich wartości poetyckiej niż znaczeniowej. W przypadku reklamy jest oczywiście inaczej, mamy tu do czynienia z obłąkanie rabunkową gospodarką zasobami leksykalnymi i im bardziej skuteczna chce być reklama, tym bardziej nie do odrobienia straty powoduje. Nie można przeprowadzić płomienia po loncie, nie niszcząc lontu. Zawsze mamy tu do czynienia z redukcją, odrobiny luksusu do mydełka Fa, osobowości do koszuli, pojęcia do przedmiotu, wartości do rzeczy. Pojawienie się reklam zmienia sytuację poezji w dużo bardziej zasadniczy sposób niż odzyskanie przez Polskę niepodległości. Język reklamy jest językiem poezji, reklama jest pseudopoezją. Różnica między nimi staje się trudno uchwytna, nie jest różnicą środków, ale celów. Poezja jest to reklama czegoś, co nie jest na sprzedaż? Język reklamy okrada mnie nie z pieniędzy, ale z mojego tworzywa, ponieważ istotą reklamy jest jej wielokrotność, powielanie, w trakcie którego zużywa się to, do czego reklama musi się odwoływać, nie może się ona ograniczyć, podcina gałąź, na której siedzi, więc musi przeskakiwać na drugą. Pytanie o przyszłość byłoby może pytaniem o istnienie słów jednorazowego użytku ${ }^{50}$.

Dzisiejszy rozwój reklamy sprawia, że można (zdarza się to wielu komentatorom życia literackiego) patrzeć na sztukę słowa jak na ubogą sio-

50 B. Zadura, Wróbel przy kości, „Twórczoóć” 1993, nr 3, s. 19-20, 23. Poczynione przez Bohdana Zadurę obserwacje, dotyczące werbalnych mechanizmów typowych dla reklamy, są zgodne z ujęciami, które prezentuje wielu lingwistów diagnozujących zjawisko - zob. na przykład G. Majkowska, dz. cyt., s. 322: „Chociaż wynik zmagań z językiem jest zasadniczo różny, obaj - poeta i autor tekstów reklamowych - borykają się z pustką słów wytartych, by im, choć na chwilę, przywrócić świeżość”. Por. też W. Pisarek, Stowa na ustugach reklamy, „Zeszyty Prasoznawcze" 1993, nr 3-4, s. 65-77 (ten badacz wprost odwołuje się do tekstu Zadury, swój wywód puentuje zaś końcowym fragmentem przywołanego przeze mnie cytatu - zob. tamże, s. 74, 77). 
strę ekspansywnej techniki komunikacyjnej, która nie tylko z powodzeniem przyswoiła sobie i doprowadziła do perfekcji chwyty typowe zwłaszcza dla obrazowania poetyckiego, ale $\mathrm{w}$ rezultacie przyczyniła się też do marginalizacji literatury w kulturze. Jednak relacje między reklamą a literaturą nie muszą być postrzegane jedynie w kategoriach starcia, która przebiega z nierównych pozycji. Konkurentką poezji bywa bowiem obecnie nie tylko, jak chce Zadura, reklama, ale również sama... poezja (czy w ogóle literatura), a dokładnie rzecz biorąc: jej współczesne oblicze i obecny status oraz stan posiadania, które prowokują odbiorców do wymownych buńczucznych deklaracji: „wolę dobrą reklamę od wyjątkowo głupiej, pretensjonalnej i kiczowatej książki. To jest tak, że zdarza się więcej poezji w samej reklamie niż (...) w tym, co się za poezję dzisiaj uważa i co jest wydawane w tomikach" ${ }^{\prime 1}$.

Śledząc uwarunkowania zachodzące między reklamą a literaturą, nietrudno zaobserwować, że obie formy komunikacji wychodzą sobie naprzeciw z łatwością i przyzwoleniem z obu stron, a to, co miało(by) budować między nimi napięcia czy być przyczyną nieusuwalnego konfliktu, zaczyna przemawiać na rzecz powinowactwa z wyboru. Jak się wydaje, impuls do zacierania granic między reklamą a literaturą płynie ze strony zarówno tej pierwszej, jak i tej drugiej. Jakkolwiek ta kwestia domaga się szczegółowej egzemplifikacji, można pokusić się o roboczo sformułowaną hipotezę, że za przejmowaniem przez reklamę reguł i funkcji przypisanych sztuce słowa jest odpowiedzialna w dużym stopniu sama literatura, a w każdym razie te jej dwudziestowieczne i najnowsze odmiany, które ochoczo rezygnują z innowacyjnych poszukiwań artystycznych, wyzbywają się aspiracji poznawczych i oryginalnych ambicji estetycznych, koncentrując się na dostosowywaniu środków wyrazu do marketingowej skuteczności. Estyma, z jaką obecnie odnosi się do reklamy wielu twórców, traktujących ją jako ważne źródło inspiracji, sporo mówi o aktualnej kondycji sztuki słowa ${ }^{52}$. Tworzona w XX i XXI wieku literatura w swoich najbardziej ekspansywnych przejawach wyraźnie dowartościowuje reklamę jako atrakcyjny wzorzec komunikacyjny. Wyzwaniem i problemem dla pisarzy okazuje się wszechobecność reklamy, która ujawnia się ,zarówno w sposób bezpośredni - w postaci plakatów, ulotek, filmów reklamowych, jak i pośredni - ma wpływ na kształtowanie się wzorców zachowania, ideałów, języka, literatury" ${ }^{33}$. Warto zatem się przyglądać

51 Takie oświadczenie złożył J. Bralczyk - zob. wywiad: Reklama i okolice..., dz. cyt., s. 24.

52 Zob. moje szczegółowe rozpoznania w osobnym artykule - M. Lachman, Pod znakiem reklamy. Literatura polska po 1989 roku $w$ kręgu oddziatywania kultury konsumpcyjnej [w:] Inna literatura? Dwudziestolecie 1989-2009, red. Z. Andres, J. Pasterski, Rzeszów 2010, t. 1, s. 41-74. Na temat odwołań do języka i atrybutów reklam w poezji polskiej po 1989 roku por. B. Bodzioch-Bryła, „W godzinę twojej śmierci - zdrapka”. O jezyku reklamy [w:] tejże, Ku ciatu post-ludzkiemu. Poezja polska po 1989 roku wobec nowych mediów i nowej rzeczywistości, Kraków 2006, s. 161-191.

53 E. Szczęsna, Reklama - pastisz i metateza czyli... „dwa w jednym”, dz. cyt., s. 212. Por. tejże, Poetyka reklamy, dz. cyt., s. 216-222. 
zbliżeniom literatury i reklamy nie tylko od strony przeobrażeń samej reklamy, ale i z punktu widzenia przemian zachodzących w obrębie sztuki słowa ${ }^{54}$. W ten sposób reklama chyba na najbardziej naturalnych zasadach może zaistnieć w optyce stricte literaturoznawczej, stając się przedmiotem zainteresowania historyków, teoretyków i krytyków literatury.

\section{Bibliografia}

Arnold R., Just do it! Nike jako sztuka publiczna, tłum. M.K. Wasilewski, „Czas Kultury" 1999, nr 3-4, s. 20-23.

Balcerzan E., Nowe formy w pisarstwie i wynikające stad porozumienia [w:] Humanistyka przetomu wieków, red. J. Kozielecki, Warszawa 1999.

Benjamin W., Wystawiennictwo, reklamy, Grandville [w:] tegoż, Pasaże, red. R. Tiedemann, tłum. I. Kania, Kraków 2005.

Bernstein D., Billboard - reklama otwartej przestrzeni, tłum. E. Ciszkowska, Warszawa 2005.

Bodzioch-Bryła B., ,W godzine twojej śmierci - zdrapka”. O jezyku reklamy [w:] tejże, Ku ciatu post-ludzkiemu. Poezja polska po 1989 roku wobec nowych mediów i nowej rzeczywistości, Kraków 2006.

Bogatyriew P., Okrzyki przekupniów ulicznych i wędrownych rzemieślników - znaki reklamy, tłum. I. Szymanowska [w:] tegoż, Semiotyka kultury ludowej, wstęp, wybór i oprac. M.R. Mayenowa, Warszawa 1979.

Bond J., Kirshenbaum R., Oszukać radar. Jak mówić do konsumenta, który nie chce stuchać, tłum. M. Wajda, Warszawa 2001.

Boorstin D.J., Amerykanie. Fenomen demokracji, tłum. J. Kozak, Warszawa 1995.

Bralczyk J., Jezyk na sprzedaż, czyli o tym, jak jezzyk stuży reklamie i jak reklama używa jezyka, wyd. 2, Gdańsk 2004.

Bratkowska M., Kolory życia do wynajęcia, „Magazyn Gazety Wyborczej” 1997, nr 32, dod. do „Gazety Wyborczej” 1997, nr 184.

Czubińska M., Polski plakat secesyjny ze zbiorów Muzeum Narodowego w Krakowie, Kraków 2003.

Czudowska-Kandyba I., Czy reklamę można rozpatrywać jako sztukę? [w:] Estetyka reklamy, red. M. Ostrowicki, Kraków 2002.

${ }^{54}$ Istnieją już prace czyniące tę kwestię przedmiotem różnokierunkowego namysłu - zob. na przykład J. Wicke, Advertising Fictions. Literature, Advertising and Social Reading, New York 1988; tejże, James Joyce and Consumer Culture [w:] The Cambridge Companion to James Joyce, red. D. Attridge, wyd. 2, Cambridge 2006, s. 234-253; G. Leonard, Advertising and Commodity Culture in Joyce, Gainesville 1998; tenże, Advertising and Religion in James Joyce's Fiction. The New (Improved!) Testament [w:] James Joyce and Popular Culture, red. R.B. Kershner, Gainesville 1996, s. 125-138; J. Strachan, C. Nally, Advertising, Literature and Print Culture in Ireland, 1891-1922, London 2012. Por. też M. Lachman, Literatura wobec reklamy. Rekonesans [w:] Literackie reprezentacje doświadczenia, red. W. Bolecki, E. Nawrocka, Warszawa 2007, s. 451-480. 
Derda P., Billboard - wytwór kultury masowej czy dzieto sztuki? (Uwagi optymisty), „Kultura Współczesna” 2000, nr 3.

Dorfles G., Reklama: retoryka a semantyka, tłum. T. Jekiel [w:] Cztowiek zwielokrotniony, tłum. T. Jekiel, I. Wojnar, przedmowa I. Wojnar, Warszawa 1973.

Dunin-Wąsowicz P., Bystrzy dyletanci, „Lampa” 2005, nr 1.

Eco U., Nieobecna struktura, tłum. A. Weinsberg, P. Brawo, Warszawa 1996.

Elgozy G., Paradoksy reklamy. Perswazja legalna, tłum. K. Błoński, wstęp K.T. Toeplitz, Warszawa 1973.

Estetyka reklamy, red. M. Ostrowicki, Kraków 2002.

Fiut I.S., Rozważania o utworze reklamowym, „Zeszyty Prasoznawcze” 1993, nr $3-4$.

Gibbons J., Art and Advertising, London-New York 2005.

Głowiński M., Poetyka wobec tekstów nieliterackich [w:] tegoż, Prace wybrane, red. R. Nycz, t. 2: Narracje literackie i nieliterackie, Kraków 1997.

Głowiński M., Reklama [w:] Stownik terminów literackich, red. J. Sławiński, wyd. 3 poszerz. i popr., Wrocław 1998.

Głowiński M., Okopień-Sławińska A., Sławiński J., Zarys teorii literatury, wyd. 6 popr., Warszawa 1991.

Główczewski A., „Oddaje tobie, co kryje w sobie”. Uwagi o semantyce przekazu reklamowego [w:] W przestrzeni komunikacyjnej. Szkice z historii i teorii dramatu, teatru i komunikacji spotecznej, red. J. Skuczyński, Toruń 1999.

Godzic W., Reklama, czyli poezja masowa, „Gazeta Telewizyjna”, dod. do „Gazety Wyborczej" 2000, nr 95.

Gołaszewska M., Zarys estetyki. Problematyka, metody, teorie, wyd. 3 uzup., Warszawa 1986.

Hayakawa S.I., Poetry and Advertising, „ETC. A Review of General Semantics” 1946, t. 3, nr 2.

Ind N., Wielkie kampanie reklamowe, tłum. M. Jóźwicka, Warszawa 2001.

Jakobson R., Problemy poetyki, tłum. A. Brosz [w:] Teoria badań literackich za granica. Antologia, red. S. Skwarczyńska, t. 2: Od przetomu antypozytywistycznego do roku 1945, cz. 3: Od formalizmu do strukturalizmu, Kraków 1986.

Kisielewski A., Poetyka obrazu reklamowego [w:] Ekspansja obrazów. Sztuka i media w świecie wspótczesnym, red. B. Frydryczak, Zielona Góra-Warszawa 2000.

Kisielewski A., Reklama - sztuka czy ikonosfera? [w:] Estetyka reklamy, red. M. Ostrowicki, Kraków 2002.

Kisielewski A., Sztuka i reklama. Relacje między sztuka i kultura, Białystok 1999.

Kita M., Literatura popularna w perspektywie jezykoznawczej [w:] Polonistyka w przebudowie. Literaturoznawstwo - wiedza o jezzyku - wiedza o kulturze - edukacja. Zjazd Polonistów, Kraków, 22-25 września 2004, red. M. Czermińska i in., t. 2, Kraków 2005.

Kochan M., Slogany w reklamie i polityce, Warszawa 2005.

Krajewski M., Zamiast sztuki - zamiast reklamy [w:] Publiczna przestrzeń dla sztuki?, red. M.A. Potocka, Kraków-Wiedeń 2003. 
Lachman M., Literatura wobec reklamy. Rekonesans [w:] Literackie reprezentacje doświadczenia, red. W. Bolecki, E. Nawrocka, Warszawa 2007.

Lachman M., Pod znakiem reklamy. Literatura polska po 1989 roku w kregu oddziatywania kultury konsumpcyjnej [w:] Inna literatura? Dwudziestolecie 19892009, red. Z. Andres, J. Pasterski, t. 1, Rzeszów 2010.

Leonard G., Advertising and Commodity Culture in Joyce, Gainesville 1998.

Leonard G., Advertising and Religion in James Joyce's Fiction. The New (Improved!) Testament [w:] James Joyce and Popular Culture, red. R.B. Kershner, Gainesville 1996.

Lewiński P., Retoryka reklamy, wyd. 2 zm., Wrocław 2008.

Lipowicz W., Zysk i powinność. Dzieto sztuki w polskiej reklamie turystycznej $w$ latach trzydziestych [w:] Sztuka dwudziestolecia międzywojennego. Materiaty Stowarzyszenia Historyków Sztuki, Warszawa, październik 1980, red. A. Marczak, Warszawa 1982.

Lisowska B., Urok nieaktualności. Ikonosfera malowanych reklam ściennych, „Kultura Współczesna” 2002, nr 3-4.

Lubelska K., Jarzyna w reklamie, „Polityka” 2004, nr 21.

Łebkowska A., Między antropologia literatury i antropologia literacka, , Teksty Drugie" 2007, nr 6.

Majkowska G., Język reklamy [w:] Polszczyzna ali Polacy u schytku XX wieku, red. K. Handke, H. Dalewska-Greń, Warszawa 1994.

Mitologie popularne. Szkice z antropologii wspótczesności, red. D. Czaja, Kraków 1994.

Moralność obrazu, z O. Toscanim rozm. W. Kocołowski, „Przekrój” 2001, nr 7.

Mrowczyk E., Reklama [w:] Stownik literatury popularnej, red. T. Żabski, Wroclaw 1997.

Musiałowska E., Reklama w komunikacji międzykulturowej [w:] Pomiędzy kulturami. Szkice z komunikacji międzykulturowej, red. M. Ratajczak, Wrocław 2006.

Muszyński A., Przypadek Benettona [w:] Mitologie popularne. Szkice z antropologii wspótczesności, red. D. Czaja, Kraków 1994.

Na Jezusa wpadtem na Siódmej, z O. Toscanim rozm. J. Mikołajewski, „Duży Format” 2002, nr 2, dod. do „Gazety Wyborczej” 2002, nr 243.

Nasiłowska A., O cudownych skutkach herbatki z melisy, „Teksty Drugie” 1991, nr 5.

Nie tylko plakat. Polska grafika reklamowa Dwudziestolecia, koncepcja, wybór i oprac. tekstów T. Lachowski, [b.m.] 2003.

Permanentny remanent. Polska grafika reklamowa $w$ czasach PRL-u, koncepcja, wybór i oprac. tekstów T. Lachowski, [b.m.] 2006.

Pisarek W., Stowa na ustugach reklamy, „Zeszyty Prasoznawcze” 1993, nr 3-4.

Płachecki M., Pragmatyka plakatu pierwszomajowego (1945-1970) [w:] Spoteczne funkcje tekstów literackich i paraliterackich, red. S. Żółkiewski, M. Hopfinger, K. Rudzińska, Wrocław 1974. 
Pomieciński A., Reklama w kulturze wspótczesnej. Studium antropologiczne, Poznań 2005.

Potocka M.A., Absolut Art Collection, „Odra” 1998, nr 5.

Radajewski A., Sztuka reklamy - reklama sztuki, „Kierunki” 1987, nr 15.

Ratajczak W., Pulower Wielkiego Brata, czyli Nie po oczach!, „Czas Kultury” 1997, nr 5-6.

Reklama i okolice. Z Jerzym Bralczykiem rozmawia Jacek Warchala, „Świat i Słowo” 2006, nr 2.

Reklama nasza powszednia [numer monograficzny], „Świat i Słowo” 2006, nr 2.

Sławiński J., Jedno z poruszeń w przedmiocie [w:] Prace wybrane, red. W. Bolecki, t. 3: Teksty i teksty, Kraków 2000 (pierwodruk: „Teksty” 1975, nr 4).

Stownik pojęć i tekstów kultury. Terytoria stowa, red. E. Szczęsna, wyd. 3 popr., Warszawa 2002.

Šmid W., Metamarketing, Kraków 2000.

Spitzer L., Amerykańska reklama jako sztuka popularna, tłum. K. Biskupski [w:] Jezyk i społeczeństwo, red. M. Głowiński, tłum. J. Arnold i in., Warszawa 1980.

Stafiej L., Manipulo, „Impact” 1999, nr 1.

Stępień T., Poezja ulicy [w:] Dwudziestowieczna ikonosfera $w$ literaturach europejskich. Wizualizacja w literaturze, red. B. Tokarz, Katowice 2002 (pierwodruk: „Opcje” 2001, nr 3-4).

Stępień T., Zabawa - poetyka - polityka, Katowice 2002.

Strachan J., Nally C., Advertising, Literature and Print Culture in Ireland, 18911922, London 2012.

Szablowska A.A., Tadeusz Gronowski. Sztuka plakatu i reklamy, Warszawa 2005.

Szczęsna E., Aforyzm a slogan - język jako zdarzenie fikcji, „Teksty Drugie” 2004, $\mathrm{nr} 1 / 2$.

Szczęsna E., Narracja jako chwyt tekstowy [w:] Opowiadanie w perspektywie badań porównawczych, red. Z. Mitosek, Kraków 2004.

Szczęsna E., Opowiadanie i media, „Pamiętnik Literacki” 2002, z. 2.

Szczęsna E., Poetyka mediów. Polisemiotyczność, digitalizacja, reklama, Warszawa 2007.

Szczęsna E., Poetyka reklamy, Warszawa 2001.

Szczęsna E., Reklama - pastisz i metateza, czyli... „dwa w jednym”[w:] Ostrożnie z literatura! (przyktady, wyktady oraz inne rady), red. S. Balbus, W. Bolecki, Warszawa 2000.

Szczęsna E., Reklama - sztuka czy perswazja?, „Dialog” 1992, nr 11.

Sztuka reklamy? [dyskusja z udziałem J. Dybczyńskiego, K. Jakubowicza, M. Janickiego, J. Witkowskiego, D.J. Cirlić], „Dialog” 1992, nr 11.

Szymkowska-Bartyzel J., „Nie mów, że chcesz go ztowić”, czyli reklama zakamuflowana [w:] Kultura popularna, red. W. Godzic, A. Fulińska, M. Filiciak, Kraków 2002.

Themerson S., Hau! Hau!, czyli kto zabit Ryszarda Wagnera [w:] tegoż, Generat Piesc i inne opowiadania, Warszawa 1980. 
Tomasik W., Wakacje na Wyspach Bahama (o perswazji socrealistycznej - dopowiedzenie) [w:] Rozgrywanie światów. Formy perswazji w kulturze wspótczesnej, red. I. Iwasiów, J. Madejski, Szczecin 1994.

Toscani O., Reklama uśmiechnięte ścierwo, tłum. M. Misiorny, [b.m.] [b.r.].

Wicke J., Advertising Fictions. Literature, Advertising and Social Reading, New York 1988.

Wicke J., James Joyce and Consumer Culture [w:] The Cambridge Companion to James Joyce, red. D. Attridge, wyd. 2, Cambridge 2006.

Wroński M., Gdyby Mickiewicz byt copywriterem..., „AIDA Media” 1998, nr 6.

Zadura B., Wróbel przy kości, „Twórczość” 1993, nr 3. 